\title{
Agency Problems and \\ the Allocation of International \\ Environmental Grants: The Return to Rio ${ }^{1}$
}

\author{
July 11, 2003 \\ Roger D. Congleton \\ Center for Study of Public Choice \\ George Mason University \\ Fairfax, VA 22030
}

\section{Introduction: International Agency Problems}

International agreements often create new international organizations with responsibility for monitoring specific issues of mutual interest and recommending policies to the participating nations. There are several reasons why the creation of new standing organizations may advance the shared interests of treaty signatories. First, in most cases, no preexisting agency focuses on the issues of interest. Consequently, there are many economic advantages associated with creating a new organization. A standing organization "learns by doing," which increases the knowledge base directed at the issues of interest. A standing organization reduces the transactions costs of addressing both continuing new areas of mutual concern. Specialization and continuity reinforces these advantages. Second, there are political advantages. In well-designed agencies, the agency internalizes the joint interests of the participating nations. Such an agency will develop policies and note problems of mutual interest, and will provides an organized "interest" group that supports those shared interests.

However, creating effective international organizations is more difficult than creating an equivalent national bureaucracy, because many nations will share responsibility

\footnotetext{
1 I would like to thank Gordon Smith for data assistance, and the participants at a seminar in Rome for helpful comments and suggestions. This research, as most of my work on environmental politics, was initially supported by the International Institute at George Mason University, whose support is gratefully acknowledged.
} 
for designing, funding, and monitoring international organizations. All these tasks are public goods for individual national governments and national citizens. A negotiator who reports to his political principal(s) that a particular organizational structure is the best that can be achieved cannot be held entirely responsible for the internal structure and decision-making rules of an international body. A government that reneges on its funding or monitoring commitments cannot be arrested by tax authorities for attempting to free ride.

Once created, an international organization that is inefficient or neglects the common interests of political principals cannot easily be punished because doing so requires nearly as much international coordination as the original formation of the agency. ${ }^{2}$

Responsibility for international organizations is diffuse in nearly all dimensions. Both the "inputs," the resources provided to the agency, and its "outputs," policies and recommendations, are joint products of the efforts of many independent national governments, representatives, and agency employees. As a consequence, international agencies are among the most likely places to exhibit political agency problems. Several agency problems are possible. First, in many cases, advancing the joint interests of the international community requires neglecting the narrow interests of individual nations. To the extent that national interests conflict with the international policy agenda of the agency, there may be conflicts between agents who diligently advance their own nation's interests and the agreed mission of the international agency. ${ }^{3}$

2 In most cases, implementing international agreements requires domestic legislation regarding regulations or taxation. That is to say, the actual enforcement of new environmental rules remains a domestic matter. Even with domestic ratification, alternative interpretations of treaty language often allow considerable discretion over how treaties are implemented. See Congleton (1994) for a discussion of domestic incentives for noncompliance that continue to exist throughout the life of a given treaty.

The present analysis neglects these problems in order to focus on international agencies. Although international agencies can rarely mandate behavior by nations, they can draw attention to problems and suggest solutions. In this manner, international organizations tend to reduce the implementation problems for those who ratify treaties.

3 Partly this source of agency problem exists because there is a conflict between the existance of national soveriegnty and delegating authority to international organizations. To surrender policy making authority to an international organization is to give up soverienty, national independence, in those policy areas. Delegation implies that ruling parties within a nation lose control over a subset of national policies that may well affect their own political interests. In cases where national policy makers are willing, in principle, to delegate considerable authority to an international organziation, the problems of properly designing those organizations may cause nations to fear international agency problems. Clearly, no head 
Second, agents may have policy interests that differ systematically from the nations that they represent, as argued in Congleton (2002). Such agents may neglect their home country's policy interests at the margins of choice because decisions of international organizations are joint products that cannot be blamed on any single agent. It is possible that such national principal-agent problems may advance the interests of the international community insofar as agent interests align with those of the international agencies' policy mission. For example, to the extent that the individuals working at international environmental agencies tend to be greener than pivotal decisionmakers in their home countries, their policy interests will cause international agencies to have a stronger interest in maximizing environmental quality than typical of the nations represented. Such agents will tend to increase environmental quality worldwide even in cases where such policies fail to advance the interests of their home countries-- who might, for example, be more interested in maximizing aid grants to their home countries. If the "right" policy-interested persons can be found, diffuse responsibilities may actually help advance the shared interests of signatories. However, not every policy interest is compatible with an international agency's formal responsibilities.

Third, as ordinary men and women, members of international organizations have the usual pecuniary interests in wealth, fame, travel, comfort, and leisure that my conflict with both their national and international responsibilities. These commonplace agency problems are potentially greater in international organizations because monitoring agency performance is a public good. It may be moderated somewhat if agent policy interests are well aligned with the mission agreed to by the sponsoring countries, but, even in this case, pecuniary interests tend to imply that agency goals will not be advanced at least cost.

All three of these principal-agent problems are likely to be evident in intra-agency deliberations and policy decisions affecting the international community (Vaubel and Willett, 1991).

This paper attempts to assess the extent to which international agency problems are present in international environmental organizations. It bears noting that agency problems tend to be smaller for environmental organizations than for many others, because it will be 
relatively easy to find agents whose personal policy agendas are well aligned with shared international interests in promoting environmental problems. However, as noted, agency problems are likely to exist in this case as well.

To characterize the extent of those agency costs, models of the funding and policy choices of a well-functioning international environmental agency are developed, and estimated using data from the Global Environmental Facility (GEF). In these policy areas, GEF has a relatively clear objective function and a measurable policy instrument measurable in dollars. One of GEF's many responsibilities is to administer environmental grants created by the Rio treaties. If agency problems are present, they will be evident in GEF allocation of environmental grants. The empirical section of the paper attempts to determine whether efforts to increase environmental quality or agency problems play a greater role in the allocation of grant moneys by GEF.

\section{The Return to Rio}

It is generally recognized that most environmental problems are a special case of the externality problem. The effluents of one group of individuals impose unaccounted costs on others not directly involved in setting the activity level of interest; consequently,. Pareto excessive effluent generating activity levels are chosen. It is less widely recognized that the same logic applies to many efforts by governments to regulate effluent emissions. In many cases, efforts by the governments to regulate effluents within their jurisdictions affect the welfare of individuals living outside their jurisdictions. Since the interests of citizens of other jurisdictions are not directly represented in local political decision making processes, local environmental regulations at the Nash equilibrium tend to be less stringent than required for Pareto optimality (Hoel, 1991).

In a federal system, such regulatory externality problems can be addressed by appealing to higher levels of governance. Higher levels of government may legislate laws which apply to all the districts affected, or may enforce agreements reached between local governments. In the case of international externality problems, such policy tools and enforcement methods are not possible. Sovereignty implies that each nation makes its own policies. Sovereignty implies that the only feasible method of addressing international 
regulatory problems is voluntary agreements--Coasian contracts--at the level of nation states.

Consequently, the problems addressed in international treaty negotiations are in many ways fundamentally different from those addressed in domestic regulation.

International treaties address externality problems among governments rather than among ordinary citizens. Treaties and international organizations with responsibility for implementing the policies agreed to attempt to influence the behavior of sovereign nations rather than the behavior of firms and consumers. It is national governments that make the treaty commitments, national governments who directly or indirectly staff the organizations, and national governments who most directly are affected by both treaty obligations and the actions of the international organizations formed.

\section{A. The Rio Earth Summit}

The "Earth Summit" in Rio De Janeiro in 1992 differed in several ways from previous forums on international environmental matters. First, the range of parties directly involved in negotiating the treaties was substantially larger than in previous forums. The principals included government representatives from more than 160 countries and, for the first time, nongovernmental organizations. Previous treaties were largely promoted and written by Western developed countries (see Benedict 1991). Second, partly as a consequence of the latter, the negotiations included consideration of issues that are not environmental in the usual sense. Issues of foreign aid, income redistribution, children's rights, women's rights, and world peace are explicitly addressed. Third, the wider agenda of these treaties implies that decisions to sign these treaties were not based entirely on the expected gains from coordinating environmental policies. Fourth, several separate environmental treaties were negotiated simultaneously. Treaties on climate control, biodiversity, and sustainable forest management were considered simultaneously. Previous agreements had been negotiated one at time. Parallel treaty negotiation provides opportunities for explicit log rolling among the treaties, which can make agreements easier to reach. 
As true of the previous CFC agreements, the Rio treaties specified different environmental and economic obligations for the developed (Annex 1) and less developed countries (Annexes 2 and 3). That is to say, developed and undeveloped countries effectively sign different environmental treaties. Generally speaking, undeveloped countries accept relatively minor changes in their future environmental standards in exchange for what the treaties call "technology transfer," where technology transfer is partly a matter of better access to unpublished scientific results, but also conditional grants. The developed countries generally accept more significant treaty obligations and also agree to provide the funds that will support the environmental grants made to the less developed countries. ${ }^{4}$

In the terms of Congleton (1994), the Rio treaties were largely procedural rather than substantive treaties. The signatory nations agreed to continue discussing issues associated with climate control and biodiversity, and to provide modest financial support for the technology transfers to annex 2 and 3 countries, as they had previously done for the CFC treaties. As typical of environmental treaties, treaty language is often vague in both environmental and nonenvironmental sections of treaty documents and little provision is made to enforce the environmental commitments of signatory nations. For example, there are no explicit penalties for failure to make contributions to the Rio trust funds, nor a clear statement of the methods by which those funds would be used.

The lack of clear obligations and enforcement mechanisms implies that it is by not obvious that treaties will affect domestic policies, and indeed the evidence is mixed on this; ee Murdoch and Sandler (1997), or Congleton (1994, 2001).

However, noncompliance is less of a concern for the case of interest here because implementation of the technology transfer programs can be directly observed as contributions to the Rio trust funds. Clearly, the Rio obligations to support technogy transfers have been at least partly implemented by the signatories, insofar as the technology

\footnotetext{
$4 \quad$ Promises of financial and technological aid are given much attention in both the convention on climate control and the biodiversity treaties negotiated in Rio. For example, Article 4 sections 3-5 of the United Nations Framework Convention on Climate Change specify the transfer obligations of developed nations. The developing countries shall "provide such financial resources, including for the transfer of technology needed by the developing county Parties to meet the agreed full incremental cost of implementing measures covered in paragraph 1 of this article..." It bears noting that the environmental (regulatory) obligations of developing countries are also more limited than for the developed countries.
} 
transfer programs have been funded at modest levels by the signatories, and those funds have been distributed to qualifying countries. The extent to which nations undercontribute is can not be directly tested because the treaties do not provide a schedule of contributions. Whether the treaty induced contributions increase overall international environmental aid is also not obvious, but such an increase is not part of the treaty obligations.

The Rio technology transfer programs have received little attention in the press, although they may be regarded as the main substantive return of the Rio treaties. The main empirical interest of this paper is estimating how the money contributed by the Rio signatories has been distributed by the responsible international grant making agency, GEF.

\section{B. GEF: the Global Environmental Facility}

At approximately the same time that the Rio treaties came into force (1994), the Global Environmental Facility was reconstituted as a vehicle for managing international environmental projects for the World Bank and the United Nation's environmental (UNEP) and development (UNDP) programs. The Instrument for the Restructured Global Environmental Facility (IRGEF) called for GEF to manage projects on climate change, biological diversity, international waters, and ozone layer depletion (section I.2). The new GEF has a formal decision-making structure with an assembly, council, and secretariat (section III). The the council is composed of 32 members, 14 from developed countries, 16 from developing countries, and 2 from former members of the Soviet alliance. Council members are appointed by groups of member states called constituencies, and are responsible for developing policies and programs for GEF-funded activities (section III 15). Council decisions are made by a "double-weighted" super majority (section IV 25c) to be used when consensus cannot be achieved. Passage requires a 60 percent majority of council members accounting for at least 60 percent of GEF funding.

One of the main responsibilities of the reconstituted GEF is to manage the "financial mechanisms" of the Rio treaties regarding climate change and biodiversity (section 1.6). That is to say, the GEF council is ultimately responsible for allocating the resources contributed to the Rio trust funds. 


\section{Models: Donors and Agencies: On the Funding and Allocation of International Environmental Grants}

To explore the international agency problems, this paper develops a general model of the relationship between donor countries and an international environmental agency with discretion over the moneys contributed. The model is used to characterize how a "perfect" environmental agency would distribute the funds provided by donors. If the observed allocation of funds is substantially different from that of a perfect agency, we may conclude that agency problems are present.

\section{A. Donor Interests}

Suppose that the pivotal political decision maker in each donor country maximizes a utility function defined over personal income (non-environmental consumption) and an index of international environmental quality, $E$. The index of environmental quality is assumed to be an increasing function of total resources available for the international grant-making agency and the environmental risk factors, $Z$, at issue, $E=\boldsymbol{\varepsilon}\left(\Sigma D_{i}, Z\right)$. Assume that the income of the pivotal decision maker of the donor country can be characterized as a constant fraction, $\alpha$, of his country's post-contribution national income, $\mathrm{X}$, and that national income is not significantly affected by the environmental quality of the recipient countries. Contributions reduce opportunities for non-environmental consumption by the amount contributed to the international agency, so $Y_{i}=\alpha_{i}\left(X_{i}-D_{i}\right)$.

The pivotal decision maker's utility function can be written as:

$$
U_{i}=u\left(\varepsilon\left(\Sigma D_{i}, Z\right), \alpha\left(X_{i}-D_{i}\right)\right)
$$

The contributions made by donor countries can be modeled in two ways. First, donor countries may simply make contributions without much consultation or coordination of contributions levels. In this case, the overall level of contributions can be modeled as the Nash equilibrium of noncooperative game. Alternatively, the amount collected may be represented as the result of a joint optimization of all donor countries.

Treaties are clearly efforts to achieve some coordination of contributions and environmental policies. However, environmental treaties generally lack explicit enforcement 
measures and rarely specify explicit environmental or contribution targets, which suggest that they do not achieve much coordination among signatories. Empirical work on environmental treaties finds little evidence that countries significantly change their environmental policies after signing and ratifying a treaty. ${ }^{5}$ Together, these suggest that treaties achieve little coordination on voluntary contributions. In this case, aggregate donations by Rio net contributors are best approximated as the Nash equilibrium of a non-cooperative contribution game.

In the non-cooperative case, the pivotal decision maker in each country makes the contribution that maximizes its utility given the contributions of the other countries. Equation 1 implies that country $i$ sets it contributions such that:

$$
U_{E} E_{D}-\alpha U_{Y}=0
$$

Equation 2 indicates that donors contribute up to the point where the marginal value of the increase in environmental quality generated equals its marginal cost to the pivotal decision maker in the country of interest. The pivotal decision maker's tastes for environmental quality (marginal utility), the marginal productivity of the international environmental agency, and the subjective marginal cost share of the pivotal decision maker jointly determine each nation's decision to make contributions.

Together with the implicit function theorem, equation 2 implies that a country's contributions can be represented as a function of national income, the share of that income that accrues to the pivotal decision maker, and the contribution level of all other countries, $\mathrm{D}^{\circ}$ :

$$
D i^{*}=\operatorname{di}\left(\alpha_{i}, X_{i}, Z, D^{o}\right)
$$

The implicit function differentiation rule implies that the partial derivatives of the donor country's contribution function, $D_{i}^{*}$, are:

\footnotetext{
$5 \quad$ Although more treaties have been signed, it is by no means obvious that these treaties actually affect domestic environmental policies. See Congleton (1994), Sandle (1995), or Congleton (2002). Consideration of the problem of treaty enforcement can be neglected in the present analysis because it focuses on moneys actually made available and distributed by GEF. That is to say, the extent to which nations undercontribute is not of interest here; rather, the main interest is how those moneys are distributed.
} 


$$
\begin{aligned}
& D_{X}^{*}=\left[\alpha U_{E Y} E_{D}-\alpha^{2} U_{Y Y}\right] /\left[-U_{D D}\right]>0 \\
& D^{*}=\left[\left(X_{i}-D_{i}\right) U_{E Y} E_{D}-\alpha\left(X_{i}-D_{i}\right) U_{Y Y}-U_{Y}\right] /\left[-U_{D D}\right]<>0 \\
& D^{*_{D o}}=\left[-\alpha U_{E Y} E_{D}+\alpha^{2} U_{Y Y}\right] /\left[-U_{D D}\right]<0 \\
& D_{Z}^{*}=\left[U_{E E} E_{Z} E_{D}+U_{E} E_{D Z}-\alpha U_{Y E} E_{Z}\right] /\left[-U_{D D}\right]>0
\end{aligned}
$$

The denominator of these derivatives is the second order condition for the optimization problem, which is assumed to be strictly concave and, hence, less than zero. Three of four numerators can be unambiguously signed. Country i will donate more to the international agency as national income increases and as perceived environmental risks increase, but less to the international agency as the total contributions of other donors increase. The effect of the portion of the relative income received by the pivotal decision maker is ambiguous because an increase in $\alpha$ has two effects. First it increases the pivotal voter's income, which tends to increase his interest in making contributions to the international environmental agency, but, under the assumptions applied here, it also increases the price of those contributions, because he or she is assumed to pay a constant fraction of the cost of those contributions. If the relative price effect dominates the income effect, contributions will fall as the share of GDP realized by the pivotal voter increases.

At the Nash equilibrium, similar first order conditions hold for all donor countries simultaneously.

$$
D_{i}^{* *}=d_{i}\left(\alpha_{i}, X_{i}, Z\right)
$$

\section{B. The Agency's Mission: Advancing International Environmental Quality}

In addition to characteristics of the pivotal political decision makers, it is clear that each donor's interest in supporting the international environmental agency is also affected by the productivity of the environmental agency, $\mathrm{E}_{\mathrm{D}}$ in equation 2 . Donors to international environmental programs clearly have an interest in creating an agency that maximizes environmental quality. There are essentially two methods by which environmental quality 
can be promoted by an international environmental agency. The agency can attempt to promote current environmental projects and allocate its budget $\left(\mathrm{D}^{* *}\right)$ to maximize the direct environmental impact of agency resources by allocating agency's resources to the worst environmental problems. Alternatively, the agency can attempt to maximize political support for the international environmental agenda by "purchasing" support for that agenda.

It bears noting that the allocation of resources that advances these environmental and political agendas are quite different from one another. Resources that are used for one will not generally effectively advance the other. To see this, consider the pattern of allocation that maximizes environmental quality.

Recall that effluents tend to increase with the production of goods and services and tend to fall with the extent to which a country is democratic because democratic countries are inclined to adopt relatively strict environmental laws (see Congleton 1992, or Murdock and Sandler, 1997). In the present analysis, authoritarian regimes differ from democratic ones because authoritarian regimes have pivotal voters that receive relatively higher shares of GDP as personal income.

Grants from the international organization are assumed to address environmental problems directly. That is to say, even lump sum grants for environmental projects are assumed to increase somewhat the total resources available for environmental agencies, as suggested by the "fly paper" literature in public finance. Consequently, country i's environmental quality, $\mathrm{E}_{\mathrm{i}}$, can be written as a function of national output, $\mathrm{X}_{\mathrm{i}}$, government type $\alpha_{i}$, country-level environmental risks, $Z_{i}$, and the environmental grant allocated to country i, $G_{i}$,

$$
E_{i}=e\left(G_{i}, X_{i}, \alpha_{i}, Z_{i}\right)
$$

Given contribution level $\mathrm{D}^{* *}$, an agency that attempts to directly improve environmental quality will allocate its resources to maximize environmental quality index $\mathrm{E}$ $=\Sigma$ Ei. The two country case is sufficient to illustrate the general properties of interest here. The agency's objective function can be written as:

$$
E=e\left(G_{1}, Y_{1}, \alpha_{1}, Z_{i}\right)+e\left(D^{* *}-G_{1}, Y_{2}, \alpha_{2}, Z_{i}\right)
$$


Differentiating with respect to $G_{1}$ allows the environmental quality-maximizing allocation of grants to country 1 to be characterized as:

$$
E_{1 G 1}-E_{2 G 2}=0
$$

which implies that:

$$
E_{1}^{*}=e\left(D^{* *}, X_{1}, \alpha_{1}, Z_{1}, X_{2}, \alpha_{2}, Z_{2}\right)
$$

Grants should be allocated so that the marginal increase in environmental quality among countries is equalized for the last dollar spent.

The implicit function theorem implies that larger environmental grants should be targeted to relatively developed countries with relatively authoritarian regimes and special environmental risks:

$$
\begin{aligned}
G^{*}{ }_{X} & =\left[E_{G Y}\right] /-\left[E_{1 G 1 G 1}-2 E_{1 G 1} E_{2 G 2}+E_{2 G 2 G 2}\right]>0 \\
G^{*}{ }_{\alpha} & =\left[E_{G \alpha}\right] /-\left[E_{1 G 1 G 1}-2 E_{1 G 1} E_{2 G 2}+E_{2 G 2 G 2}\right]>0 \\
G^{*}{ }_{Z} & =\left[E_{G Z}\right] /-\left[E_{1 G 1 G 1}-2 E_{l G 1} E_{2 G 2}+E_{2 G 2 G 2}\right]>0
\end{aligned}
$$

This environmental quality maximizing allocation of resources can be contrasted with that of a political-support maximizing agency. An agency that attempts to maximize support for the international environmental agenda focuses on the welfare of pivotal decision makers within the polities of interest rather than environmental quality. Support for a specific treaty arrangement increases as the net improvement in the welfare of a pivotal decision maker increases,

$$
S_{i}=s\left(u\left(E_{i}, \alpha\left(X_{i}+G_{i}\right)-u\left(E_{i}^{0}, \alpha X_{i}\right)\right) .\right.
$$

A political support-maximizing agency will allocate its budget $D^{* *}$ to maximize, $\mathrm{S}=\Sigma \mathrm{S}_{\mathrm{i}}$. Again the two country allocation problem is sufficient to illustrate the factors that 
determine the environmental agency's allocative choice. In this case, total support can be represented as:

$$
\begin{aligned}
S= & s\left(u\left(e\left(G_{1}, Y_{1}, \alpha_{1}\right), \alpha_{1}\left(X_{1}+G_{1}\right)-u\left(E^{0}, \alpha_{1} X_{1}\right)\right)+\right. \\
& s\left(u\left(e\left(D^{* *}-G_{1}, Y_{2}, \alpha_{2}\right), \alpha_{2}\left(X_{2}+D^{* *}-G_{1}\right)-u\left(E^{0}{ }_{2}, \alpha_{2} X_{2}\right)\right)\right.
\end{aligned}
$$

Differentiating with respect to $\mathrm{G} 1$ yields an expression characterizing the optimal allocation of grant money to country 1.

$$
S_{\Delta 1}\left(U_{E} E_{G 1}+\alpha U_{Y 1}\right)-S_{\Delta 2}\left(U_{E} E_{G 2}+\alpha U_{Y 2}\right)=0
$$

An agency that attempts to promote the environmental quality by maximizing political support should allocate funds to equalize the marginal gains in support from the last dollar spent in each country, rather than marginal gains in environmental quality.

In the case where the marginal gain in support generated by an increase in pivotal decision-maker welfare is approximately the same, $\mathrm{S}_{\Delta 1}=\mathrm{S}_{\Delta 2}$, and equation 12.1 can be rewritten as:

or

$$
\left(U_{E 1} E_{G 1}+\alpha U_{Y 1}\right)-\left(U_{E 2} E_{G 2}+\alpha U_{Y 2}\right)=0
$$

$$
\left(U_{E 1} E_{G 1}+\alpha U_{Y 1}\right)=\left(U_{E 2} E_{G 2}+\alpha U_{Y 2}\right)
$$

In this case, grants should be allocated to equalize the marginal gains in the pivotal decision-maker welfare. Equation 12.3 shows this the political allocation of grants is only partly based on environmental effects. In addition to environmental effects there are effects on national income that are relevant for the pivotal decision maker. In general, the implicit function theorem implies that the support maximizing grants that country i receives will vary with its national characteristics and those of other countries eligible for the grants.

$$
G_{1}^{*}=g\left(D^{* *}, X_{1}, \alpha_{1}, Z_{1}, Y_{2}, \alpha_{2}, Z_{2}\right)
$$

Equation 13 and equation 7 appear to be very similar insofar as they direct attention to the same country characteristics. However, the effects of national income and 
government type in the political support maximizing allocation of grants differ from that of the environmental quality maximizing allocation. The difference can be demonstrated by differentiating equation 13 with respect to national income $X_{i}$, income share $\alpha_{i}$ and environmental risk factor, $Z_{i}$ :

$$
\begin{aligned}
& G_{X}^{*}=\left[\left(\alpha U_{E Y} E_{G}+U_{E} E_{G Y}+\alpha^{2}\left(U_{Y Y}+U_{Y E} E_{Y}\right)\right] /-\left[S_{G 1 G I}\right]<0\right. \\
& \text { (if } x \text { dominates) } \\
& G^{*} \alpha=\left[(X+G) U_{E Y} E_{G}+U_{Y}+\alpha(X+G) U_{Y Y}+\right. \\
& \left.U_{E E} E_{Y} E_{G}+U_{E} E_{G Y}+\alpha U_{Y E} E_{Y}\right] /-\left[S_{G 1 G I}\right]>0 \text { (if } x \text { dominates) } \\
& G^{*}{ }^{\prime}=\left[U_{E Z 1} E_{G 1}+U_{E l} E_{G Z 1}+\alpha U_{Y Z 1}\right)- \\
& \left.\left(U_{E Z 2} E_{G 2}+U_{E 2} E_{G Z 2}+\alpha U_{Y Z 2}\right)\right] /-\left[S_{G 1 G 1}\right]>0 \quad\left(\text { if } Z_{1}>Z_{2}\right)
\end{aligned}
$$

Only the effect of environmental risk on grants can be signed unambiguously.

Other things being equal, the extent of noneconomic environmental risk factors continues to affect the allocation of resources by affecting the extent to which environmental quality can be improved by grant dollars given existing domestic environmental policies. If political risks are greater in country 1 than in country 2, country 2 should receive more resources, other things being equal. However, in contrast to the preceding case, neither the effect of national income nor that of authoritarian regime are unambiguously determined. Both income and environmental effects are relevant in this case and, to some extent, work in opposite directions. In the case where the income effects $(\mathrm{x})$ of transfers dominate the effects of environmental quality for pivotal decision makers, wealthier countries should receive smaller grants than poorer countries.

\section{Empirical Evidence: Who Gives and Who Gets the Money?}

The above analysis suggests that at least two general patterns of grants are consistent with the aim of improving environmental quality. First, conditional environmental grants may directly promote environmental policy formation in less developed countries. Such grants should be targeted at relatively rich authoritarian regimes with high environmental risks. Second conditional environmental grants may indirectly promote environmental 
quality by increasing political support for environmental treaties and other environmental policies. Such grants should be allocated to relatively poor authoritarian regimes with serious environmental risks.

Agency problems may be said to exist if the pattern of grants is inconsistent with these methods of promoting the environmental agenda. For example, the international agency might "misdirect" grant-making resources to projects of special interest to agency decision makers. For example, in the case of GEF, the council members are representatives of their home countries, and consequently their career interests at home may be advanced by directing relatively large grants to their home countries.

\section{A. The Data and Model's Estimated}

Quadratic forms of equations 5, 8, and 13 are estimated for GEF to determine the extent to which GEF resources are raised and allocated in a manner consistent with the models. The estimates allow us to determine whether grants are allocated to promote economic or political methods of advancing the international political agenda, and the extent to which the allocation of grants promote an environmental agenda at all. Efforts to increase political support rather than environmental quality can be distinguished from one another, because a support-oriented program will tend to target relatively more grants at undeveloped (low income) countries and an environmental program will target more at relatively more developed (high income) countries.

Data on GEF's allocation of environmental grants are reported in the 2001 GEF regional reports. The annexes of these reports list grants made to individual countries under the Rio biodiversity and climate control treaties for the decade prior to July 2001 in millions of US dollars, and the extent of matching resources, if any, provided by recipient countries. Regional and global projects are also listed, although not how those expenditures are allocated among countries. Consequently, only the national grant data are used below. These provide the most direct evidence of GEF's allocative decisions. Data on national contributions to GEF are not readily available, but some data on recent contributions for specific programs are available from its web site. For example, data on promises and actual contributions to the biodiversity program in 2001 are listed on the GEF web site. 
Data on country characteristics are collected from the World Bank's World Development Indicators CDrom (2000). Data on per capita national income measured in purchasing parity dollars are from the World Bank. Data on government type are taken from the Freedom House data on political liberties. Countries in the two categories with the fewest political liberties are coded as dictatorships. Those with two categories with the most political liberties are coded as democracies. As proxies for environmental risks, $\mathrm{CO}_{2}$ emissions per unit of economic output and population density are computed from data provided on the World Indicators data set. Table 1 summarizes the data used for the model estimates.

\begin{tabular}{|c|c|c|c|}
\hline \multicolumn{4}{|c|}{ Table 1} \\
\hline \multicolumn{4}{|c|}{ Data Set: Sample Characteristics and Sources } \\
\hline Variable & Sample Mean & Sample Variance & Source \\
\hline GPD per capita (PPP) & 6412.219 & 58276424.35 & World Bank \\
\hline Population & 30708336.142 & 13306627643866300 & World Bank (1995) \\
\hline Area & 708130.642 & 3652116465748.36 & World Bank \\
\hline $\begin{array}{l}\text { Government Type } \\
\text { (Political Liberties) }\end{array}$ & 3.429 & 4.908 & $\begin{array}{l}\text { Freedom House/ } \\
\text { World Bank }\end{array}$ \\
\hline Annex 1 Country & 0.169 & 0.141 & Treaty Document \\
\hline Member GEF Council & 0.159 & 0.134 & $\begin{array}{l}\text { GEF annual Report } \\
2001\end{array}$ \\
\hline $\begin{array}{c}\text { Contributions to } \\
\text { Biodiversity Program }\end{array}$ & 12158.104 & 5252681984.273 & GEF Web Report 2001 \\
\hline Biodiversity Grants & 7.717 & 161.674 & GEF Regional Report 2001 \\
\hline Climate Control Grants & 8.067 & 620.593 & GEF Regional Report 2001 \\
\hline
\end{tabular}




\section{B. Estimated Contribution Schedule}

Equation 4 suggests that, at the Nash equilibrium, contributions from donor countries tend to rise with income and with perceived environmental risks. Column 1 of Table 2 estimates a quadratic form of equation 5, using per capita GDP as a proxy for national income and the countries own population density and $\mathrm{CO}_{2}$ emissions per dollar of GDP as a proxy for its perception of environmental risks. Although the estimates are consistent with the model insofar as the estimated coefficients all have the correct signs, none are statistically distinguishable from zero.

Columns 2 and 3 include estimates that more fully represent the perceived environmental and agency risks of contributors. Other political factors are also taken account of. Column 2 includes a binary variable for developed countries, the so-called Annex 1 countries as listed in the Kyoto protocol. Annex 1 countries tend to be wealthier than non-Annex 1 countries and have the clearest treaty obligation to make contributions to the biodiversity trust fund. Column 3 also includes binary variables that indicate whether the country has signed and ratified the biodiversity treaty and whether the country has direct representation on the GEF Council. The former represent perceived environmental risks (or national demands for biodiversity), and the latter represents smaller agency risks. These specifications fit the data better and, again, have the predicted signs. Contributions rise as perceived environmental risks increase and as national income increases, and are generally lower for dictatorships than for nondictatorships. 


\section{Table 2}

Estimates of National Contribution Schedules

\begin{tabular}{|c|c|c|c|}
\hline & $\begin{array}{c}2001 \text { Biodiversity } \\
\text { Contributions } \\
\text { (LS) }\end{array}$ & $\begin{array}{c}2001 \text { Biodiversity } \\
\text { Contributions } \\
\text { (LS) }\end{array}$ & $\begin{array}{c}2001 \text { Biodiversity } \\
\text { Contributions } \\
\text { (LS) }\end{array}$ \\
\hline $\mathrm{C}-$ & $\begin{array}{c}14750.76 \\
(0.91)\end{array}$ & $\begin{array}{c}6117.948 \\
\quad(0.40)\end{array}$ & $\begin{array}{c}-7191.596 \\
(-0.37)\end{array}$ \\
\hline GNP-PPP & $\begin{array}{l}-2.954 \\
(-0.76)\end{array}$ & $\begin{array}{l}-3.818 \\
(-1.06)\end{array}$ & $\begin{array}{l}-3.331 \\
(-0.77)\end{array}$ \\
\hline$(\text { GNP-PPP })^{2}$ & $\begin{array}{l}9.25 \mathrm{E}-005 \\
\quad(0.62)\end{array}$ & $\begin{array}{l}0.0001 \\
(0.76)\end{array}$ & $\begin{array}{l}6.74 \mathrm{E}-005 \\
\quad(0.39)\end{array}$ \\
\hline Democracy & $\begin{array}{c}17313.7 \\
(0.96)\end{array}$ & $\begin{array}{c}17669.29 \\
(1.05)\end{array}$ & $\begin{array}{l}15034.63 \\
(0.72)\end{array}$ \\
\hline Dictatorship & $\begin{array}{c}-3267.115 \\
(-0.17)\end{array}$ & $\begin{array}{c}-8209.474 \\
(-0.47)\end{array}$ & $\begin{array}{l}-16203.41 \\
(-2.89)^{* *}\end{array}$ \\
\hline $\mathrm{CO}_{2} \mathrm{EMIT} / \mathrm{GNP}$ & $\begin{array}{c}1.28 \mathrm{E}+013 \\
(1.89)^{*}\end{array}$ & $\begin{array}{c}1.14 \mathrm{E}+013 \\
(1.81)^{*}\end{array}$ & $\begin{array}{c}2.94 \mathrm{E}+013 \\
(2.90)^{* * *}\end{array}$ \\
\hline Population Density & $\begin{array}{l}1.073 \\
(0.06)\end{array}$ & $\begin{array}{c}6.538 \\
(0.408)\end{array}$ & $\begin{array}{l}11.201 \\
(0.64)\end{array}$ \\
\hline $\begin{array}{l}\text { GEF-Council } \\
\text { Member }\end{array}$ & & & $\begin{array}{l}71252.16 \\
(3.50)^{* * *}\end{array}$ \\
\hline $\begin{array}{l}\text { Annex } 1 \\
\text { Country }\end{array}$ & & $\begin{array}{c}83354 \\
(4.94)^{* * *}\end{array}$ & $\begin{array}{l}77857.44 \\
(3.67)^{* * *}\end{array}$ \\
\hline $\begin{array}{c}\text { Biodiversity Treaty } \\
\text { Ratified }\end{array}$ & & & $\begin{array}{c}301.675 \\
(1.89)^{*}\end{array}$ \\
\hline $\begin{array}{l}\text { Biodiversity Treaty } \\
\text { Signator }\end{array}$ & & & $\begin{array}{l}-312.901 \\
(-1.91)^{*}\end{array}$ \\
\hline R-squared & 0.034 & 0.17 & 0.32 \\
\hline F-Statistic & 0.852 & $4.33 * * *$ & $4.99 * * *$ \\
\hline $\begin{array}{l}\text { Number of } \\
\text { Observations }\end{array}$ & 152 & 152 & 117 \\
\hline
\end{tabular}




\section{Estimated GEF Allocation Schedule}

Once collected, the efficient allocation of those resources by an international environmental agency is described by equation 8 if the agency pursues the direct economic method of advancing environmental quality and by equation 13 if the agency pursues the indirect political method of advancing the international environmental agenda. In either case, the environmental grant received by a country will increase with its environmental risks and tend to be larger for dictatorships than for democracies insofar as the environmental problems within dictatorships tend to be larger. The economic method implies that more grants go to relatively more industrialized countries and less to unindustrialized ones. The political method suggests that poorer countries will receive relatively larger grants than richer countries.

Column 1 of table 3 reports estimates of the allocation of both climate control and biodiversity grants by GEF for the 1991-2001 period. The estimates are somewhat consistent with the predictions of the economic model insofar as grants rise with income and are relatively more generous to dictatorships than to democracies. However, the estimated coefficients for the environmental risk factors have the wrong sign. Grants fall with $\mathrm{CO}_{2}$ emissions per unit of GNP and population density! Column 2 estimates a model of Rio-grant allocation that distinguishes Annex 1 countries and GEF Council members. Columns 3 and 4 report estimates for the biodiversity and climate control grants, separately. 


\section{Table 3}

Estimated Pattern of GEF Rio Grants

$($ Rio $=$ Biodiversity + Climate Control $)$

\begin{tabular}{|c|c|c|c|c|}
\hline & $\begin{array}{l}\text { Rio Grants } \\
\quad \text { (LS) }\end{array}$ & $\begin{array}{l}\text { Rio Grants } \\
\text { (LS) }\end{array}$ & $\begin{array}{l}\text { Biodiversity } \\
\text { (LS) }\end{array}$ & $\begin{array}{l}\text { Climate Control } \\
\text { (LS) }\end{array}$ \\
\hline $\mathrm{C}$ & $\begin{array}{c}13.964 \\
(2.29)^{* *}\end{array}$ & $\begin{array}{l}9.798 \\
(1.63)\end{array}$ & $\begin{array}{c}5.097 \\
(2.40)^{* *}\end{array}$ & $\begin{array}{l}4.465 \\
(1.01)\end{array}$ \\
\hline GNP-PPP & $\begin{array}{c}0.003 \\
(2.26)^{* *}\end{array}$ & $\begin{array}{c}0.003 \\
(2.53)^{* *}\end{array}$ & $\begin{array}{c}0.001 \\
(2.00)^{* *}\end{array}$ & $\begin{array}{c}0.002 \\
(2.44)^{* *}\end{array}$ \\
\hline$(\mathrm{GNP}-\mathrm{PPP})^{2}$ & $\begin{array}{c}-1.20 \mathrm{E}-007 \\
(-2.18)^{* *}\end{array}$ & $\begin{array}{c}-1.25 \mathrm{E}-007 \\
(-2.37)^{* *}\end{array}$ & $\begin{array}{c}-3.84 \mathrm{E}-008 \\
(2.04)^{* *}\end{array}$ & $\begin{array}{l}-8.64 \mathrm{E}-008 \\
(-2.24)^{* *}\end{array}$ \\
\hline Dictatorship & $\begin{array}{l}-12.516 \\
(-1.77)^{*}\end{array}$ & $\begin{array}{l}-11.951 \\
(-1.78)^{*}\end{array}$ & $\begin{array}{l}-3.858 \\
(-1.69)^{*}\end{array}$ & $\begin{array}{c}-7.946 \\
(4.93) * * *\end{array}$ \\
\hline Democracy & $\begin{array}{c}-17.719 \\
(-2.65)^{* *}\end{array}$ & $\begin{array}{c}-16.048 \\
(-2.51)^{* *}\end{array}$ & $\begin{array}{l}-3.298 \\
(-1.38)\end{array}$ & $\begin{array}{c}-11.889 \\
(4.69) * * *\end{array}$ \\
\hline Population Density & $\begin{array}{l}-0.004 \\
(0.70)\end{array}$ & $\begin{array}{l}-0.004 \\
(-0.64)\end{array}$ & $\begin{array}{l}-0.002 \\
(-0.70)\end{array}$ & $\begin{array}{l}-0.002 \\
(-0.49)\end{array}$ \\
\hline $\mathrm{CO}_{2} \mathrm{EMIT} / \mathrm{GNP}$ & $\begin{array}{c}-4.65 \mathrm{E}+009 \\
(-1.83)^{*}\end{array}$ & $\begin{array}{c}-5.03 \mathrm{E}+009 \\
(-2.07)^{* *}\end{array}$ & $\begin{array}{c}-2.00 \mathrm{E}+009 \\
(-2.32)^{* *}\end{array}$ & $\begin{array}{c}-2.99 \mathrm{E}+009 \\
(1.67)^{*}\end{array}$ \\
\hline Annex 1 Country & & $\begin{array}{c}-15.49 \\
(2.08)^{* *}\end{array}$ & $\begin{array}{c}-8.791 \\
(-3.65) * * *\end{array}$ & $\begin{array}{l}-6.049 \\
(-1.10)\end{array}$ \\
\hline GEF Council Member & & $\begin{array}{c}25.121 \\
(3.71)^{* * *}\end{array}$ & $\begin{array}{c}11.575 \\
(4.87)^{* * *}\end{array}$ & $\begin{array}{c}12.901 \\
(2.59)^{* *}\end{array}$ \\
\hline R-squared & 0.086 & 0.178 & 0.224 & 0.124 \\
\hline F-Statistic & $2.137^{*}$ & $3.607 * * *$ & $5.167 * * *$ & $2.32 * *$ \\
\hline $\begin{array}{l}\text { Number of } \\
\text { Observations }\end{array}$ & 142 & 142 & 142 & 142 \\
\hline
\end{tabular}

* denotes statistical significance at the 0.10 level, $* *$ at the 0.05 level, and $* * *$ at the 0.01 level.

As net contributors, with relatively strong domestic regulations and sophisticated waste handling in their own countries, Annex 1 countries are unlikely to be recipients of technology transfer grants. On the other hand, membership on the GEF Council allows a country's representative to exercise some direct control over the allocation of grants, which 
evidently favors the countries represented to the extent that council members represent national--in addition to global--interests. The estimates confirm both distinctions. Annex 1 countries receive smaller grants than non-Annex 1 countries. GEF Council members receive larger grants, other things being equal. The latter is direct evidence of international agency problems.

Overall, these estimates suggest that GEF Council members attempt to advance environmental goals insofar as environmental problems rise with income and decline with democratic governance. The estimates also suggest that GEF Council members advance the interests of their home countries, insofar their home countries tend to receive larger grants than other countries, other things being equal. Whether the latter is an agency problem or not depends on whether the GEF Council members are regarded to be agents of the global community or of their home countries.

On the other hand, the relatively poor, although statistically significant, explanatory power of the estimated models suggests that general environmental circumstances either do not fully capture the environmental conditions that draw GEF's attention, or that significant nonenvironmental agendas are being advanced by the Global Environmental Facility. Insofar as the indicators chosen are faithful indicators of international environmental risks within the countries in the sample and international environmental problems are significant aims of the international community, the results suggest that agency problems or nonenvironmental interests are important determinants of the distribution of international environmental grants.

\section{Grant Type as Additional Evidence of Agency Objectives}

Additional evidence of GEF objectives can be taken from the kinds of projects supported. Economics suggests that the types of grants given out, matching or lump sum, can be used as evidence of the methodology used by GEF to advance environmental goals. Elementary public finance suggests that conditional lump-sum grants tend to increase the welfare of recipients more than equivalent matching grants and, therefore, will tend to generate a greater increase in political support than will equivalent matching grants. Public finance also implies that matching environmental grants tend to have a greater effect on 
environmental quality, because they induce countries to spend more of their own resources on environmental programs. In other words, matching grants attract new resources to environmental projects, whereas conditional lump sum grants tend to release existing environmental expenditures for other purposes.

In the context of the present analysis, the use of conditional lump sum grants suggests that political support is being "purchased" from grant-receiving countries, whereas the use of matching grants suggest that environmental improvements are the principal target. The GEF regional reports indicate that about half of the biodiversity and climate control grants are conditional lump-sum and half are matching grants.

This pattern of grant types suggests that the political and environmental agendas are being pursued simultaneously. This mixed policy regime provides a possible explanation for the relatively modest estimated effects of national income on grants received.

\section{Conclusions}

Essentially all international agencies confront public goods and agency problems analogous to those explored in this paper. What makes environmental agency problems of particulary interest is a combination of contemporary policy issues and conceptual differences. The newspapers clearly suggest the international environmental issues are pressing political concerns in all democracies. To the extent that international agencies will be the vehicle for addressing those problems, the present paper suggests that international environmental problems will not be easy to address even if treaties are signed and new organizations are formed. The problem of providing proper incentives for international agencies is very difficult in general.

Conceptually, these problems may be somewhat smaller for international environmental agencies than most others because it is relatively easier to find talented individuals with a clear interest in international environmental problems to staff international environmental agencies. To the extent that relatively "green" bureaucrats are attracted to international environmental agencies, agencies will clearly be inclined to maximize the environmental improvements that can be generated by a given budget. The "green" policy agenda is substantially an international one. Moreover, in many cases 
international environmental interests are straightforward and quantitative. Outputs of green house gases are measurable, as are atmospheric densities. Biodiversity cannot be measured as precisely, but is nonetheless measureable within broad limits. Together the "objective" policy agendas of the Rio treaties and the relative ease with which international agencies may be staffed with persons very interested in those problems suggests that international agency problems tend to be smaller in environmental matters than in other international policy areas.

However, the estimates provided above suggest that agency problems within international environmental organizations remain very significant. The statistical evidence developed in this paper suggests that GEF does not simply maximize international environmental quality based on broad national risk factors. Although the qualitative features of GEF's allocation of environmental grants are broadly consistent with maximizing environmental quality, the estimates explained less than half of the distribution of environmental grants.

It is possible that GEF has been more faithful to the international environmental agenda than revealed by the estimates. For example, environmental risk factors have not been properly measured. Other "micro" environmental concerns may drive GEF's allocation of the Rio environmental grants. Additional research would clearly be useful here. However, it would be surprising to find that such micro-environmental considerations broadly advance the transnational concerns that motivated the international community to negotiate and ratify the Rio treaties on climate control and biodiversity. The most likely explanation for the difference between an efficient allocation of environmental grants and that observed is that GEF decision making is not entirely consistent with maximizing international environmental quality. The present results show that public choice and economic analysis can only partly explain the pattern of GEF grant making.

The ultimate impact of the Rio treaties and GEF on environmental and foreign policies will not be known for many years, but it seems clear that both agency and public goods problem will continue to affect the development of international environmental policy. The present analysis suggests that these problems are not absent from the relatively easy task of allocating environmental grants among countries. "Technology transfer" grants 
are partly consistent with Rio goals, but not entirely so. The continuing negotiations over climate control agreed to at Rio also appear to exhibit a variety of principal agent and public goods problems at the level of nations that will be difficult to completely resolve.

The general features of the problems studied in this paper clearly apply to other international policy areas as well. Indeed, agency and public goods problems are likely to be even greater in other international policy areas where the personal policy interests of international bureaucrats are less likely to be well-aligned with international policy interests. 


\section{References}

Benedict, R. E. (1991) Ozone Diplomacy. Cambridge Mass: Harvard University Press.

Black, D. (1987/1958) The Theory of Committees and Elections, Boston: Kluwer Academic Publishers.

Buchanan, J. M. and Tullock, G. (1975) "Polluters' Profits and Political Response, Direct Control Versus Taxes," American Economic Review 65: 139-147.

Buchanan, J. M. and Congleton R. D. (1998) Politics by Principle, Not Interest: Towards Nondiscriminatory Democracy. Cambridge: Cambridge University Press.

Coase, R. H. (1960) "The Problem of Social Cost," Journal of Law and Economics 3:1-44.

Congleton, R. D. (1992) "Political Institutions and Pollution Control," Review of Economics and Statistics 74: 412-421.

Congleton, R. D. (1995) "Toward a Transactions Cost Theory of Environmental Treaties: Substantive and Symbolic Environmental Agreements," Economia Delle Scelte Pubbliche (1995): 119-139.

Congleton, Roger D. Ed. (1996) The Political Economy of Environmental Protection: Analysis and Evidence. Ann Arbor, Michigan: University of Michigan Press.

Congleton, R. D. (2001) "Governing the Global Environmental Commons: The Political Economy of International Environmental Treaties and Institutions," in Schulze, G. G. and Ursprung, H. W. Eds. Globalization and the Environment. New York: Oxford University Press, pp. 241-263.

Congleton, R. D. (2002) "Policy Interests as a Source of Public Agency Problems: Some Evidence from International Environmental Treaties," Fairfax: Center for Study of Public Choice Working Paper.

Hoel, M. (1991) "Global Environmental Problems: The Effects of Unilateral Actions Taken by One Country," Journal of Environmental Economics and Management 21: 55-70.

Lott, John R. Jr. (1990) "Predation by Public Enterprises", Journal of Public Economics, vol. 43, pp. 237-251. 
Maloney, M. T. and McCormick, R. E. (1982) "A Positive Theory of Environmental Quality Regulation," Journal of Law and Economics, 25: 99-123.

M'Gonigle, R. M. and Zacher, M. W. (1979) Pollution, Politics, and International Law, Berkeley: University of California Press.

Mintzer, I. M. and Leonard, J. A. (1994) Negotiating Climate Change. New York: Cambridge University Press.

Mueller, D. C. (1989) Public Choice II, Cambridge: Cambridge University Press.

Murdoch, J. C. and Sandler, T. (1997) "The Voluntary Provision of a Pure Public Good: The Case of Reduced CFCs Emissions and the Montreal Protocol," Journal of Public Economics 63: 331-349.

Niskanen, W. A. Jr. (1971) Bureaucracy and Representative Government, Chicago, Aldine-Atherton.

Sandler, T. (1997) Global Challenges: An Approach to Environmental, Political, and Economic Problems. Cambridge: Cambridge University Press.

Schulze, G. G. and Ursprung, H. W. Eds. (2001) Globalization and the Environment. New York: Oxford University Press.

Smith, T. T. Jr. and Kromarek, P. (1989) Understanding US and European Environmental Law, Boston: Martinus Nijhoff.

Telser, L. (1980) "A Theory of Self-Enforcing Agreements," Journal of Business 53: 27-44.

Tollison R. D. and Willett, T. D. (1979) "An Economic Theory of Mutually Advantageous Issue Linkages in International Negotiations," International Organization 33: 309-346.

Vaubel, R. and Willett, T. D., Eds. (1991) The Political Economy of International Organizations, Boulder: Westview Press.

Weingast, B. R., and Moran, M. J.(1983) "Bureaucratic Discretion or Congressional Control? Regulatory Policymaking in the Federal Trade Commission", Journal of Political Economy 91: 765-800. 
